\title{
FAMILY ALLOWANCE FOR SOCIAL CHILD PROTECTION - REFERRAL TO THE RIGHT TO CHILD ALLOWANCE
}

\begin{abstract}
Family allowance for social protection of children is defined in the Law on Protection of Children, as follows: children allowance, special allowance, single financial assistance for a new-born child and parental allowance for a child. The thesis deals with the most common social financial assistance for the family with children and their right to child allowance.

Most often, the child allowance is granted to all families whose total family income is below a certain financial threshold and is designed to help cover the costs of supporting a child to a certain age. Sometimes this right is conditioned by the employment of parents, schooling of children, vaccines and health examinations.

The European Union Law prescribes that child's allowances/benefits of the child allowance are taken over the country of residence where the EU citizen lives or works, regardless of the nationality. Thus, by applying the comparative method, the thesis makes an overview of the realization of the right to child allowance in some of the EU countries.

Using the legal and sociological method, an analysis of the right to child allowance in the Republic of North Macedonia is also elaborated.

Further in the thesis, a combination of quantitative and qualitative research methods is used, analysing secondary data. The main instrument used in the thesis analysis is the critical review of the applicable legislation concerning the right to child allowance and the system of social protection of children.
\end{abstract}

Keywords: SOCIAL BENEFITS, SOCIAL PROTECTION, CHILDREN, RIGHTS, EUROPEAN UNION, REPUBLIC OF NORTH MACEDONIA

\section{Introduction}

The most common form of social financial assistance for a family with children is the child allowance. This is one of the methods the state uses to help cover the rising cost of living in order to preserve the standard of living. In different countries there are different laws / programs according to which the right to child allowance is implemented differently. Thus, in some countries, the child allowance is associated with the employment of parents, and in others with the material status of the family or they link it with the 
fulfilment of certain conditions, such as school enrolment of children, health examinations and vaccines. The universalization is the modern tendency of this allowance - the user is every child.

At the beginning of the new millennium child poverty and social exclusion were identified by national governments and international organizations as a significant issue holding future consequences that could lead to complicated social problems. Duffy defines social exclusion as "low material means and inability to participate effectively in economic, social and cultural life, and, in some characteristics, alienation and distance from the mainstream society" (Duffy, 1995 in Klasen, 1998). When it comes to children, it should be added that they "are citizens who are entitled to rights and capabilities, "social exclusion" is an issue violating their rights and capabilities directly (...) and decisions, choices, and opportunities in childhood will crucially affect their position as adults, the impact of issues such as education and socialization on their likely social exclusion as adults will have to be examined as well". In 2001 the European Commission announced that for the first time child poverty was higher than the rate by adults $-19 \%$ of children in Europe were living in low-income households at the risk of poverty (European Commission, 2003 in Hoeshler, 2004). As a result, serious efforts coming from the EU member states were invested in order to prevent child poverty and social exclusion (Hoeshler, 2004). In the European Union $29.4 \%$ of total GDP is spent for social protection and $8.08 \%$ of them are oriented toward family and children benefits (Eurostat, 2014). The social system in each European country has developed policies oriented toward helping families in raising their children (Antonova, Katsarska, 2014). Using the Open Method of Coordination member states developed their family support policies. Families were granted benefits in-cash or under social investments in order to cover child's expenses (Nelson, 2009). The amount of the allowance is determined depending on the number of children in the family and their age. In some countries (including our country), the child allowance is a measure of social as well as of population policy. The law more precisely regulates the conditions for fulfilling the right, the amount etc., related to the average earnings per employee member of the family.

Under Regulation 883/2004, in the EU, family benefits and all allowances are intended to cover family costs. In EU member states, different types of allowances are considered to be family benefits, for example, parental allowance, child allowance, multi-family allowance, childcare allowance for special needs, and etc.

If a certain person performs activities as an employed or a self-employed person, uses the right to a pension or is temporarily residing in an EU member state, the same right may be practiced in the EU member state aforementioned even if the child does not reside in that specific country but resides in one of the EU member states. In the case where all family mem- 
bers live in the same EU member state whose legislation is applicable on the basis of employment or self-employment, pension or temporary residence, then the right to family benefits may be practiced in this country of residence only.

However, if members of the family temporarily reside in one EU member state but not in the country where the applicant has acquired the right on the basis of employment or self-employment, the use of pension or permanent residence, the right to family benefits may be practiced in several member states. ${ }^{1}$

\section{Methods of fulfilment of the right to child allowance in some EU coun- tries}

\subsection{France}

The right to child allowance is used by parents or any person who has children under their responsibility. There are three types of family allowance from which general child-raising allowances have the traits of child allowance. Parents can get an allowance when they have their second born child. General child-raising allowances also depend on the working status of parents or caregivers.

There are, family allowances - paid with a second child up to 20 years, the amount is adjusted according to the number of children and depends on the income of the family; flat-rate family allowance - for three or more children; family income supplement - for three or more children between the ages of 3 and 21, depending on the income in the family or household; Family Support Allowance - payable regardless of income, for each child with one parent or orphans. Parents are also entitled to early childhood benefits that constitute birth allowance or adoption as one-time assistance. And, special benefits for children who have access to children with special needs up to 20 years of age or children who are accommodated in special schools or have specific home help. The supplement is paid through a separate "CAF" - Family Benefits Office (Directorate-General for Employment, Your social security rights in France, 2018, 6-9).

\footnotetext{
${ }^{1}$ In the EU the right to family allowances is regulated by: Regulation (EC) No 883/ 2004 of the European Parliament and of the Council of 29 April 2004 on the coordination of social security systems, Regulation (EC) No 987/2009 of the European Parliament and of the Council of 16 September 2009 laying down the procedure for implementing Regulation (EC) No 883/2004 on the coordination of social security systems, Regulation (EU) No 1231/2010 of the European Parliament and of the Council of 24 November 2010 extending Regulation (EC) No 883/2004 and Regulation (EC) No 987/ 2009 to nationals of third countries who are not already covered by these Regulations solely on the ground of their nationality.
} 


\subsection{Germany}

„Kindergeld“ or child allowance is granted to the child under 18 years of age and in certain circumstances up to 25 years of age. This amount is equal for every child and is not affected by the income of the parents, guardians or the family where the child lives. It aims to reimburse some of the cost of raising a child. This right applies to anyone who is registered and resides in Germany and who has a biological or adopted child. The allowance is received by children aged 18-25 if the child is in school, is not employed, but is registered as a person who is actively seeking work or children who due to the psycho-physical condition are not able to support themselves (Directorate-General for Employment, Your social security rights in Germany, 2018, 6-8).

\subsection{Sweden}

In 1937, the child allowance was only granted to poor mothers. In 1948 , this was first acquired by all families with children, and the condition was that parents are socially insured in the country. There are: a child allowance that is automatically received by children up to 16 years of age; extended child allowance for children of regular schooling over 16 to 20 years of age or when the schooling is completed, in that case the payment is made through the Swedish Board for Student Finance and a supplement for a large family meaning a family with multiple children, without specifying the amount, for children up to the age of 20 is paid in addition to the child allowance, and from 16-20 years of age only the supplement for a large family is paid, provided that the children live with the family, are in regular schooling and not married. In 2018, the amount was 1250 SEK per month ( $€ 119.70)$ and the payment of funds can be shared between parents. The payment is made through the SSIA - Social Security Insurance Agency (Directorate-General for Employment. Your social security rights in Sweedish, 2018, 6-14).

\subsection{Croatia}

Every parent, foster parent or children without parents are entitled to a child allowance, if the applicant has a place of residence for at least 3 years in the country. The second condition is that the total income in the previous calendar year does not exceed $50 \%$ of the accrual basis (income threshold). In other words, the average income per household member does not exceed 1,663 kuna (221 euros) per month. It is paid for children under the age of 15 years old or 19 years old. It can be extended to 21 years old for a child who has not completed school at the usual time due to illness. For children with special needs, the allowance is paid until there is such a disability (Directorate-General for Employment. Your social security rights in Croatia, 2018, 7-11). 
3. Legal position of the right to child allowance in the Republic of North Macedonia

In the Republic of North Macedonia, as a part of the children's social rights, the right to child allowance is prescribed for in the Закон за заштита на децата. ${ }^{2}$ Child allowance is the right of the child and is provided as a financial allowance for covering part of the expenses in raising and development of the child.

The right to a child allowance is practiced by one of the parents of the child, a citizen of the Republic of North Macedonia with a permanent place of residence in the Republic, for a child also citizen of the Republic of North Macedonia and a status of full-time student in the Republic, if the parent is: employed in a company, public enterprise, public institution and other legal entity performing economic activity and other legal entity performing public service activity, state body and local self-government unit and other domestic and foreign person and legal entity who employs workers with at least half of the full working hours, i.e. equal working hours; beneficiary of the rights from pension and disability insurance, according to the provisions of the Law on Pension and Disability Insurance; unemployed person receiving monetary compensation; beneficiary of permanent financial assistance; military disabled person and user of a family disability compensation; a farmertaxpayer of a tax on income who performs an agricultural activity as the only and main occupation and craftsman who carries out old crafts and craftsmen who perform craft activities that are deficient.

Child allowance is practiced depending on the age of the child and the material condition of the family. The right to child allowance is provided to a child up to 18 years of age and if the child attends full-time school, such as: a child who is a full-time primary school student by the end of the schooling for as many years as the full-time studies takes place, by August 31 ${ }^{\text {st }}$ in the current school year; and for a child who is a full time student in a high school, for each school year as of August 31 of the year but only until the child turns 18.

A child of whom the full time student status ceases to be valid is not entitled to a child allowance, and the right ceases to be applicable on the first day of the following month after the termination of that status.

A child who completely and permanently or for a period longer than a year will remain incapable of work before the age of 15 years or during full-time schooling, has the right to child allowance for the duration of the child's inability, but not later than the turning of 18 years of age. A child who has been granted a right to reach competence for work until full completion of the process but no later than the child reaches 18 years of age is

2 „Службен весник на Република Македонија“ бр. 98/2001 од 23.11.2000 
also considered as a person completely and permanently incompetent for work.

As an exception, the right to child allowance is granted to a child who due to illness or injury is prevented from regularly attending classes and because of such incapacity; the child according to the law continues the parttime education .

Children's allowance is practiced for children who are supported by the parent, for children born in marriage or out of wedlock, adopted children, as well as for grandchildren, brothers, sisters and other children taken for support.

For the dependent children, a child allowance also is practiced for children with parents, but if: their parents are completely or permanently incapable of work; are serving a prison sentence; their parental rights have been revoked and parents are on full time schooling. For foster children, a child allowance is practiced when parents and children have no property or income from which they can support the children. A child allowance also applies to a child who is without parental care, and is placed in a foster family.

A child allowance is not provided for a child who, due to parenting, education or training, is in an institute or institution in which the child is residing completely free of charge while in the institute or institution and for a child who is a citizen of Republic of North Macedonia for which the parent practiced the right to a child allowance in accordance with the regulations of another country.

The material status of the family is determined based on the income generated by the family and the number of family members.

The right to child allowance has a child in a family whose income per family basis for 2019 is 2,587.11 denars and for a single parent child is up to 5,174.22 denars.

The amount of the child allowance for 2019 is: for a child of preschool age and for a child student in a primary school 744 denars; and for a child student in secondary school until the age of 18 years is 1,180 denars.

For children who are completely and permanently incapable of work, the amount of a child allowance is determined as follows: for a child who is completely and permanently incapable of work until the age of 15 years is 744 denars; and for a child who is completely and permanently incapable of working for over 15 years of age until he is 18 years of age is 1,180 denars.

With the transition of the child from elementary to secondary school, the amount of child allowance from the first month of the school year changes. Especially for a child who completely and permanently or for more than one year becomes incapable of work, before the age of 15 or during full-time schooling, as well as for a child who has been granted the right to work, the 
amount of child allowance is changed from the month following the completion of 15 years of age.

The procedure for practicing or extending the right to child allowance shall be initiated upon the application of the parent or guardian of the child to the social work centre, competent for the area where the applicant has its residence.

The beneficiary of the right to child allowance is obliged to inform the competent social work centre about any change in the facts and circumstances that were the basis for the grant of the right, no later than 15 days from the day the changes occurred.

The request for extension of the right to child allowance for the next year shall be submitted by 31 March of the current year. If the request for extension of the right to child allowance is submitted after this deadline, the applicant will acquire the extension or use of the right on the first day of the next month of the month in which the request for extension of the right was submitted (Закон за заштита на децата, art. 21-31). The Law of Social Protection stipulates that the Centre for Social Work decides upon the rights determined by the Law on Child Protection, as follows: child allowance, special allowance, one-time financial assistance for a new-born child and parental allowance for a child (Закон за социјална заштита, art. 133).

The detailed conditions, criteria and the manner of practicing the rights for protection of children, the child allowance is regulated in the Rulebook in the Articles from 1-12. ${ }^{3}$

\subsection{Challenges of the right to child allowance in the Republic of North Macedonia}

To reflect upon, former legal regulations restricted the right to child allowance only to the third child. Because that was discrimination against children, amendments to these legal provisions were made, and this was one of the recommendations of the Committee on the Rights of the Child. ${ }^{4}$ With the adoption of the Law on Child Protection in 2013, these provisions have changed. The new provisions do not provide for the restriction of this right to children.

According to the provisions of this Law, only children up to the age of 18 years of age are eligible for child allowance, then children whose parents are employed, pension beneficiaries, unemployed persons receiving un-

\footnotetext{
${ }^{3}$ Adopted by the Minister of Labor and Social Policy based on Article 53 of the Закон за заштита на децата, published in the "Службен весник на Република Македониja" no. 23/13.

${ }^{4}$ The Committee on the Rights of the Child is a body composed of independent experts who monitor the implementation of the 1989 Convention on the Rights of the Child by the member states.
} 
employment benefits, beneficiaries of permanent financial assistance, military disabled persons and users of a family disability compensation, farmers, craftsmen, which means that only children who have full-time education are entitled to child allowance and whose parents do not earn any income during children full-time education and whose parents do not generate any revenue, on any ground, are not entitled to child allowance.

The amendments to this Law also limit the amount of the child allowance, i.e. the maximum amount that can be presented by a family is determined, so regardless of the fact that the family has more children, it cannot reach a higher amount than the one stipulated by the law, by this, the Law once again excludes part of the kids that are part of multi-children families from their right to child compensation (Извештај на Народниот правобранител за имплементација на Конвенцијата за правата на детето и протоколите кон Конвенцијата. 2000 - 2005, 2007).

From the above mentioned, one of the most important inconsistencies is that the child allowance is limited to persons currently employed or receiving unemployment allowances. Although this is not explicitly provided by law, the Rulebook for the payment of this allowance contains inconsistencies in regard to that restriction, and according to the current application, a significant part of the population, especially the poorest, is excluded from receiving a child allowance (Зајакнуване на социјалната заштита на дециата, Анализа и препораки за поправичен и поефикасен систем на надоместоции за децุа, 2013, 5).

The reasons for the low efficiency of the child allowance can be found in questions about the design of the program and its implementation. There are problems in the program that hurt the policy objectives for covering the costs of raising and developing children in poor families. These limitations are:

1) The requirement that the beneficiary (one of the parents) must be in full-time employment or receive compensation as an unemployed person. This requirement proves to be very binding and excludes the poorest families whose members are not in full-time employment and have never been able to receive compensation as an unemployed person;

2) When calculating the income for practicing the right to compensation, for calculation of the base income, families rather than households are taken into consideration. Perhaps the children's compensation would be more effective if the household income instead of the family income is taken into consideration, as well as if mechanisms for verification of the real income of the compensation applicants are put into practice (because the family is only defined by parents and children whereas the household includes all persons residing together, regardless of the strict family relations); 
3) Informal incomes are not fully covered in the assessment of the fulfilment of the conditions for compensation, (the claimants have a tendency to misrepresent their informal income in order to practice the right to compensation and as a consequence funds are not effectively allocated); and

4) Fees are very small, which means that the impact is reduced with the increase of the number of household members. ${ }^{5}$

Also, there are several disadvantages in the implementation. The most important ones are that people are misinformed about the criteria for practicing the right to allowance and that the process for filing a claim for compensation is very complex and it costs. Consequently, there are observations that these fees are not awarded in accordance with transparent or objective criteria. However, there are no transparent grievance mechanisms, and some of the claimants in general are not informed of the results of the submitted requests (Ibid., 6).

\section{Conclusion}

From the comparison, it can be concluded that the right to child allowance varies within and between countries according to the size and type of family, depending on earning and whether a comparison of the system of tax and cash benefits is made, or only in terms of housing and service costs and benefits.

In the Republic of North Macedonia according to the existing structure and application, the child allowance, as a right of the child from social protection, does not provide an adequate standard of living for children or it does not alleviate their vulnerability and their deprivation of right, and often the most marginalized children and those most in need are not included.

To prevent child poverty and social and economic vulnerability, wellintegrated social protection systems should be developed and made upon the special needs of children, with particular emphasis on the most vulnerable.

\footnotetext{
${ }^{5}$ One way of analyzing the adequacy of the allowance is to compare the amount of the payment of the allowance with the basic costs that the households have. For example, according to a survey of users, we know that CA users per month spend 1.599 MKD per child (tuition, transportation, food in the school, etc.) and health (medications, consultancies, transport, etc.). Therefore, since a household with one child can receive a maximum of $1,115 \mathrm{MKD}$, the payment from the compensation will not cover these basic costs. The difference becomes even bigger when we consider the amount given to the second and the remaining children, where the low percentage of the basic costs is covered. (Ibid, 36).
} 


\section{References}

Antonova, D., Katsarska, D. (2014). Child Benefit Systems in Bulgaria and the United Kingdom. Rotterdam: ERASMUS UNIVERSITEIT ROTTERDAM.

Directorate-General for Employment. (2018). Your social security rights in France. Brussels: EUROPEAN COMMISSION, Social Affairs and Inclusion.

Directorate-General for Employment. (2018). Your social security rights in Germany. Brussels: EUROPEAN COMMISSION, Social Affairs and Inclusion.

Directorate-General for Employment. (2018). Your social security rights in Swedish. Brussels: EUROPEAN COMMISSION, Social Affairs and Inclusion.

Directorate-General for Employment. (2018). Your social security rights in Croatia. Brussels: EUROPEAN COMMISSION, Social Affairs and Inclusion.

Eurostat. (2014). At-risk-of-poverty rate of households with at least one dependent child by work intensity (source: SILC)\%, available at: http:// epp.eurostat.ec.europa.eu/tgm/table.do?tab=table\&init=1\&plugin=0\&1 anguage $=$ en $\&$ pcode $=$ tessi123

Klasen, S. (1998). SOCIAL EXCLUSION AND CHILDREN IN OECD COUNTRIES: SOME CONCEPTUAL ISSUES, OECD, available at: http:// www.oecd.org/edu/school/1856923.pdf

Народен правобранител на Република Северна Македонија. Одделение за заштита на правата на децата. (2007). Извештај на Народниот правобранител за имплементација на Конвенцицата за правата на детето и протоколите кон конвенциијата 2000 - 2005. Скопје.

Regulation (EC) No 883/2004 of the European Parliament and of the Council of 29 April 2004 on the coordination of social security systems.

Regulation (EC) No 987/2009 of the European Parliament and of the Council of 16 September 2009 laying down the procedure for implementing Regulation (EC) No 883/2004 on the coordination of social security systems.

Regulation (EU) No 1231/2010 of the European Parliament and of the Council of 24 November 2010 extending Regulation (EC) No 883/2004 and Regulation (EC) No 987/2009 to nationals of third countries who are not already covered by these Regulations solely on the ground of their nationality.

Зајакнување на социјалната заштита на децата, Анализа и препораки за поправичен и поефикасен систем на надоместоции за дец̧а (2015). Скопје: Канцеларија на УНИЦЕФ.

Закон за заштита на децата, консолидиран текст, 14.2.2013, со сите досегашни измени и дополнувања. 